Original Research Paper

\title{
Perangkat Pembelajaran IPA Model 5E : Kajian Kritis Hasil Workshop Guru- Guru Anggota MGMP IPA Kota Mataram
}

\author{
Dwi Soeistya Dyah Jekti ${ }^{1 *}$, Imam Bachtiar ${ }^{I}$, Prapti Sedijani ${ }^{I}$, Lalu Zulkifli ${ }^{1}$,Dadi Setiadi ${ }^{1}$ \\ ${ }^{1}$ Program Studi Pendidikan Biologi Fakultas Keguruan dan Ilmu Pendidikan, Universitas Mataram
}

\author{
*Corresponding Author: \\ Jekti, Program Studi \\ Pendidikan Biologi \\ Fakultas Keguruan dan \\ Ilmu Pendidikan, \\ Universitas Mataram, \\ Indonesia; \\ Email: \\ soelistya.dj@gmail.com
}

\begin{abstract}
Abstrak: Kurikulum Mata Pelajaran IPA SMP tahun 2017 di Kota Mataram menuntut para guru IPA untuk bisa meningkatkan keterampilan dalam mengembangkan perencanaan dan mengimplementasikannya secara baik. Salah satunya adalah guru IPA SMP bisa mengembangkan perangkat pembelajaran. Untuk dapat mengembangkan perangkat pembelajaran IPA sesuai dengan standar, para guru IPA harus memiliki keterampilan dalam mengembangkan perangkat pembelajaran, Para guru masih terpaku dengan meodel yang disarankan kemnetrian terkait, sementara banyak model pembelajaran berbasisi siswa aktif salah satunya model 5E (Engage, Explore, Explain, Extend dan Evaluate). Oleh karena itu perlu dilakukan kegiatan untuk mengmbangkan keterampilan bapak/ibu guru IPA anggota MGMP IPA dalam perangkat pembelajaran model 5E. Desain yang digunakan adalah post tes no control group design. Populasi adalah semua guru IPA anggota MGMP Kota Mataram, sampel yang digunakan sebanyak 40 guru. Pengumpulan data dilakukan dengan mengevaluasi produk berupa perangkat pembelajaran hasil kegiatan workshop. Data dianalisis deskriptif kuantitatif. Hasil menunjukan bahwa perangkat pembelajaran yang disusun oleh guru peserta $(90 \%)$ sudah baik dalam merencanakan langkah-langkah 5E. Tetapi dalam kaitannya dengan tagihan dan pengetahuan sebagian besar perangkat pembelajaran kurang mencakup keluasan dan kedalaman materi yang ditagih oleh kompetensi dasar pengetahuan dan keterampilan. Dengan demikian walaupun langkah-langkah pembelajaran berbasis siswa aktif dan memenuhi tagihan kurikulum tetapi tingkat asesmen belum memenuhi tagihan. Berdasarkan hasil penjelasan di atas dapat disimpulkan bahwa 90\% bapak ibu guru IPA dapat menyusun perangkat pembelajaran cukup baik khususnya terkait sintaks $5 \mathrm{E}$.
\end{abstract}

Kata Kunci : pembelajaran IPA, model 5E, kajian kritis

\section{Pendahuluan}

Tuntutan kurikulum 2013 revisi terbaru mata Perlajaran IPA SMP menunjukan bahwa pembelajaran harus menuntut siswa mengembangkan keterampilan ilmiah seperti model pembelajaran problem based learning, project base learning dan discovery learning (Permendikbud Republik Indonesia Nomor 65 Tahun 2013). Dengan demikian guru harus memiliki kemampuan dalam mendisain dan mengembangkan perangkat pembelajaran yang sesuai dengan tagihan kompetensi dasar, termasuk instrumen asesmen proses dan hasil belajar siswa terkait dengan pelaksanaan model pembelajaran tersebut. Menurut Permendikbud Republik Indonesia Nomor 81a Tahun 2013 bahwa kurikulum dikembangkan agar memungkinkan penyesuaian program pendidikan pada satuan pendidikan dengan kekhasan potensi peserta didik; dan memungkinkan potensi diri berkembang secara optimal. Sejalan dengan itu, kurikulum disusun dengan memperhatikan potensi, tingkat perkembangan, minat, kecerdasan intelektual, emosional, sosial, spritual, dan kinestetik peserta didik. Juga proses pembelajaran terdiri atas lima pengalaman belajar pokok yaitu: mengamati; menanya; mengumpulkan informasi; mengasosiasi; dan mengkomunikasikan. Proses 
pembelajaran sepenuhnya diarahkan pada pengembangan ketiga ranah tersebut secara utuh/holistik, artinya pengembangan ranah yang satu tidak bisa dipisahkan dengan ranah lainnya. Dengan demikian proses pembelajaran secara utuh melahirkan kualitas pribadi yang mencerminkan keutuhan penguasaan sikap, pengetahuan, dan keterampilan. (Peraturan Menteri Pendidikan dan Kebudayaan Republik Indonesia Nomor 65 Tahun 2013). Selain itu kurikulum 2013 dirancang dengan karakteristik-karakteristik tertentu, diantaranya mengembangkan keseimbangan antara pengembangan sikap spiritual dan sosial, rasa ingin tahu, kreativitas, kerja sama dengan kemampuan intelektual dan psikomotorik (Peraturan Menteri Pendidikan dan Kebudayaan Republik Indonesia Nomor 66 Tahun 2013). Kurikulum dikembangkan dengan memberikan kesempatan kepada peserta didik untuk mengembangkan perbedaan dalam kemampuan dan minat. Atas dasar prinsip perbedaan kemampuan individual peserta didik, kurikulum memberikan kesempatan kepada peserta didik untuk memiliki tingkat penguasaan di atas standar yang telah ditentukan (dalam sikap, keterampilan dan pengetahuan). (Kementerian Pendidikan dan Kebudayaan, 2012)

Dalam pengembangan konten, standar isi nasional pendidikan digunakan sebagai acuan pengembangan konten kurikulum untuk mewujudkan tujuan pendidikan nasional (Peraturan Pemerintah Pemerintah Republik Indonesia Nomor 32 Tahun 2013; Undang-Undang Republik Indonesia Nomor 20 Tahun 2003 ). Standar tersebut berupa Kompetensi Dasar mencakup sikap sosial, pengetahuan, dan keterampilan dalam muatan mata pelajaran. Kompetensi dasar dikembangkan didasarkan pada prinsip akumulatif, saling memperkuat (reinforced) dan memperkaya (enriched) antar mata pelajaran dan jenjang pendidikan (organisasi horizontal dan vertikal) (Peraturan Menteri Pendidikan dan Kebudayaan Republik Indonesia Nomor 66 Tahun 2013).

Penilaian proses dan hasil belajar merupakan penilaian yang harus dilakukan secara komprehensif untuk menilai mulai dari masukan (input), proses, dan keluaran (output) pembelajaran dan` Penilaian otentik dilakukan oleh guru secara berkelanjutan (Peraturan Menteri Pendidikan dan Kebudayaan Republik Indonesia Nomor 66 Tahun 2013). Adapun prinsipnya Terpadu, berarti penilaian oleh pendidik dilakukan secara terencana, menyatu dengan kegiatan pembelajaran, dan berkesinambungan.Penilaian hasil belajar peserta didik mencakup kompetensi sikap,pengetahuan, dan keterampilan yang dilakukan secara berimbangsehingga dapat digunakan untuk menentukan posisi relatif setiappeserta didik terhadap standar yang telah ditetapkan. Selain ituInstrumen penilaian harus memenuhi persyaratan:1) substansi yang merepresentasikan kompetensi yang dinilai;2) konstruksi yang memenuhi persyaratan teknis sesuai denganbentuk instrumen yang digunakan; dan3) penggunaan bahasa yang baik dan benar serta komunikatifsesuai dengan tingkat perkembangan peserta didik. (Peraturan Menteri Pendidikan dan Kebudayaan Republik Indonesia Nomor 66 Tahun 2013).

Pengembangan proses pembelajaran dalam implementasi kurikulum sangat dianjurkan diseuaikan dengan kondisi santuan pendidikan. Dalam konteks pengembangan proses maka diawali pengembangan rencana pelaksanaan pembelajaran termasuk lembar kegiatan peserta didik. Dari hasil penelitian salah satu model perangkat pembelajaran 5E (RPP dan LKPD) bisa meningkatkan ketiga ranah (pengetahuan, keterampilan dan sikap). Model perangkat tersebut merupakan model pengembangan yang bisa dijadikan model pembelajaran pengayaan bagi guru IPA dan peserta didik pun akan merasa termotivasi lebih baik jika guru lebih banyak atau bervariasi dalam penggunaan model pembelajaran pada mata pelajaran IPA. Namun demikian para guru harus memahami secara komprehensif terkait dengan pemahaman teoritis dan keterampilan dalam mendisain perangkat pembelajaran model $5 \mathrm{E}$.

Model 5E mengarahkan peserta didik untuk terlibat kreatif dalam setiap tahapan: Engage: Students become engaged in the process of scientific inquiry, Explore: Students consider what makes questions scientifically testable. Explain/Elaborate: Students conduct an investigation in the context of a community, Evaluate: Students deepen their understanding of scientific inquiry by performing their own investigation and evaluating one performed by another student (Bybee, et all. 2005). Selain itu, model tersebut akan membantu guru dalam pendekatan pembelajaran yang bermakna dan memperkuat peserta didik untuk belajar (Bybee, 2014). Juga pengembangan perangkat dan implementasi pembelajaran model 5E akan memberikan manfaat kepada guru terkait dengan pengayaan dalam pengembangan model perangkat 
pembelajaran yang bisa memenuhi tagihan proses dari kurikuum 2013.

Berdasarkan uraian di atas, perlu dilakukan pemberian workshop pada guru-guru IPA anggota MGMP IPA Kota Mataram yang lebih berbasis pada praktek dan pembimbingan langsung dalam penyusunan perangkat pembelajaran model $5 \mathrm{E}$ pada mata pelajaran IPA SMP untuk meningkatkan kemampuan menyusun perangkat pembelajaran model 5E.

\section{Metode}

Jenis penelitian yang digunakan dalam penelitian ini adalah penelitian deskriptif kualitatif, dan merupakan suatu metode penelitian yang digunakan untuk meneliti pada kondisi objek yang alamiah, dimana peneliti adalah sebagai instrumen kunci. Teknik pengumpulan datanya dilakukan dengan cara triangulasi (gabungan), analisis data bersifat induktif, dan hasil penelitian kualitatif lebih menekankan makna daripada generalisasi (Sugiyono, 2008a: 2008b). Dilihat dari teknik penyajian datanya, penelitian tersebut menggunakan pola deskriptif yang berusaha menggambarkan dan menginterpretasi objek sesuai dengan apa adanya. Dari definisi di atas, dapat dipahami bahwa metode penelitian kualitatif dengan pola deskriptif yang dilakukan, bermaksud menggambarkan secara sistematis fakta dan karakteristik objek atau subjek yang diteliti secara tepat. Tempat pelaksanaan di SMPN di Kota Mataram semester gasal tahun akademik 2017/2018. Desain yang digunakan adalah post tes no control group design. Populasi adalah semua guru IPA anggota MGMP Kota Mataram, sampel yang digunakan sebanyak 40 guru. Pengumpulan data dilakukan dengan mengevaluasi produk berupa perangkat pembelajaran hasil kegiatan workshop. Data dianalisis deskriptif kuantitatif.

\section{Hasil dan Pembahasan}

Keterampilan guru-guru IPA dalam mendisan dan mengembangkan rencana pembelajaran berbasis 5E mencakup komponen-komponen yang ada dalam rencana pembelajaran sebagai berikut:

Keterkaitan antara rencana program pembelajaran yang disusun guru secara keseluruhan sudah cukup artinya rencana pelaksanaan pembelajaran dikembangkan mencakup kompetensi dasar, indikator, materi, waktu dan sumber belajar. Namun demikian pennjabaran kompetensi dasar menjadi sejumlah indikator pencapaian kompetensi (IPK) masih kurang komprehensif belum mencakup tagihan dari kompetensi dasar termasuk kegiatan pembelajaran yang masih kurang menggambarkan kegiatan 5E yang sesuai tagihan dari standar proses dari kurikulum yang berlaku.

Bagian-bagian dari komponen rencana pelaksanaan pembelajanran mencakup identitas sekolah terdiri dari nama satuan pendidikan; identitas mata pelajaran kelas/semester materi pokok dan alokasi waktu untuk setiap rencana pelaksanaan pembelajaran guru-guru sudah terpenuhi artinya semua guru-guru memahami dengan baik terkait dengan identitas sekolah yang harus tercantum secara jelas dalam perencanaan pembelajaran.

Bagian IPK pada rencana pelaksanaan pembelajaran yang dirumuskan berdasarkan KD, dengan menggunakan kata kerja operasional yang dapat diamati dan diukur, yang mencakup sikap, pengetahuan, dan keterampilan untuk rencana pembelajaran yang di kaji dan analisis terdapat sejumlah kekurangan dan kesalahan. Aspek pengetahuan semua memenuhi tagihan KD dari segi cakupan dan kedalaman tagihan yang mencakup demensi kognitif dan pengetahuan. Hal ini akan menyebabkan ketidak tercapaian tujuan dari tagihan kompenetsi dasar yang akan berakumulasi pemenuhan tingkat keals dan seterusnya. Sedangkan yang mencakup sikap masih kurang tepat aspek yang diukur termasuk rubrik penilaian yang tidak jelas sehingga skor yang dihasilkan siswa pun akan tidak mewaikili keadaan sikap yang sebenarnya. Juga aspek keterampilan masih tidak jelas sesuai dengan tagihan kompetensi dasar sehingga kesesuain dengan $\mathrm{KD}$ dan isntrumen serta prosesnya kurang sesuia dengan tagihan yang ada dalam KD yang mencakup keterampilan. Selain itu juga tampak instrumen yang disusun dalam rubrik penilaian belum mewakili cakupan dan tagihan dari kompetensi keterampilan.

Hal lain adalah terkait dengan materi pembelajaran, yang harus memuat fakta, konsep, prinsip, dan prosedur yang relevan, dan ditulis dalam bentuk butir-butir sesuai dengan rumusan indikator ketercapaian kompetensi. Materi kurang sesuai dengan tagihan pengetahuan pada $\mathrm{KD}$, hal ini seharusnya dikaitkan dengan tagihan engetahuan 
tersebt kemudian ditentukan dimensi pengetahuan apakah mencakup fakta konsep dan stserusnya. Hal tersebut memerlukan perbaikan secara menyeluruh agar bisa memenuhi tagihan konten dari kompetensi dadasr terkait.

Metode pembelajaran yang digunakan oleh pendidik berutujuan untuk mewujudkan suasana belajar dan proses pembelajaran agar peserta didik mencapai KD yang disesuaikan dengan karakteristik peserta didik dan KD yang akan dicapai. Metode harus sesuai dengan tagihan hasil secara keseluruhan untuk setiap kurikulum yang berlaku terdapat sejumlah metide yang direkomendasikan agar bisa mencapai indikator pencapaian kompetensi. Metode yang digunakan terkait dengan kegiatan dalam pembelajaran 5E khusunya dalam kegiatan inti, sehingga terkait hal ini masih perlu diberikan pemahaman terkait dengan metode yang bisa memenuhi tagihan setandar proses dari kurikulum yang berlaku

Media pembelajaran yang berupa alat bantu proses pembelajaran untuk menyampaikan materi pelajaran cukup menunjukan media yang menagih proses pembelajaran lebih berbasis pada siswa akatif, artinya media yang dikembangkan oleh guru harus menyesuaikan dengan tagiha kompetensi yang harsu dimiliki peserta didik setelah selesai pembelajaran. Penggunaan media berbasis teknologi cukup merata dikuasai guru, sehinga masih memerlukan pengembangan kemamapuan yang lebih baik terkait penggunann atau pengembangan media pembelajaran.

Penggunaan sumber belajar dalam kegiatan ini berbasis 5E, dapat berupa buku, media cetak dan elektronik, alam sekitar, atau sumber belajar lain yang relevan, tetapi guru masih terbatas pada penggunaan buku sumber aja, sehingga masih diperlukan pengembangan dari internet agar bisa mengarahkan dan mengembangkan keterampilan untuk bisa mendisain dan menyedian sumber belajar yang bisa digunakan secara mudah dan berkelanjutan sesuai dengan kegiatan pembelajaran. Langkah-langkah pembelajaran dilakukan melalui tahapan pendahuluan, inti, dan penutup pada semua kurikulum hampir semua sudah mengikuti tapi masih ada sebagian kecil belum mengacu pada standar proses dan kurikulum yang berlaku. Selain itu, sebagian kecil belum memenuhi proses yang sesuai dengan tagihan proses dari kurikulum yang berlaku. Kondisi tersebut akan berpengaruh pada proses ril dari pembelajaran dan evaluasinya sehingga memerlukan penguatan pada guru terkait dengan langkah-langkah pembelajaran 5E, termasuk juga tagihan proses kurikulum 2013 yang mencakup 5M (mengamati menanya, mengobservasi, mengasosiasi dan mengkomunikasikan). Hal ini harus dipahami oleh bapak ibu guru sebelum menyusun perangkat pembelajaran. 5E Learning Cycle model is an effective hands-on and inquiry-based scientific pedagogy that enhances students' scientific knowledge and understanding (Liu, Peng, Wu, dan Lin, . 2009)

Keterampilan dalam membuat instrumen penilaian hasil pembelajaran kognitif masih kurang mencakup dan kedalaman, hal tersebut disebabkan guru kurang terampilnya dalam merumuskan tujuan/indikator atau indikator pencapaian kompetensi. Sehingga guru memerlukan latihan dan praktek terkait dengan penyusunan instrument asesmen pengetahuan. Sedangkan untuk aspek sikap belum baik tekait dengan rumusan instrument dan rubrik penilaiannnya. Sehingga para guru harus memiliki keterampilan dalam mengembangkan instrumen penilaian sikap. Selain itu untuk aspek keterampilan masih sebagian besar tidak sesuai dengan tagihan disebabkan penilaiannya kurang mencakup kriteria ketarampilan yang dinilai dilihat dari segi indikator dari keterampilan terkait. Penyusunan instrument penilaian keterampilan sama dengan sikap basiknya adalah sikap dan keterampilan apa yang dikembangkan sesuai dengan $\mathrm{KD}$, kemudian dirumuskan indikatornya dan dilanjutkan dengan perumusan indikator dan instrument asesmennya dari setiap indikator.

Lembar kegiatan peserta didik (LKPD) berbasis $5 \mathrm{E}$ secara keseluruhan sudah memnuhi tagihan proses pembelajaran termasuk keterkaitan dengan tagihan pencapaian indikator. Hal ini akan berpengaruh terhadap hasil yang hendak dicapai dengan alasan pencapaian tujuan sangat tergantung dari pengalaman belajar kegiatan pembelajaran peserta didik. Dengan demikian penyusunan LKPD bagi guru IPA perlu ditingkatkan agar bisa mencapai tujuan, kurikulum yang berlaku termasuk dalam kegatan diskusi kasus atau pertanyaan yang menuntut berpikir tinggi para peserta didik. Menurut Snajdr (2011) bahawa the 5E learning cycle has strengths and weaknesses. One weakness is that this method is likely to be more time consuming than many alternative teaching methods. but method takes a good deal of planning and will likely take 
more class time than other, more traditional, methods of instruction.Mobile learning activities based the 5E Learning Cycle model can effectively increase students' knowledge and understanding of aquatic plants and improve students' learning motivation. (Liu, Peng, Wu, dan Lin. 2009)

Secara keseluruhan komponen indikator pencapaian kompetensi, materi, metode, sumber belajar, kegiatan pembelajaran yang mencakup kegiatan pendahuluan, inti dan penutup serta insrumen untuk asesmen proses dan tujuan pembelajaran masih perlu direvisi dengan baik agar sesuai dengan standar minimal yang harus dibuat terkait dengan pengembangan perangkat pembelajaran, hal ini berhubungan dengan proses sebelum guru melaksanakan program MGMP. Dengan demikian diperlukan perbaikan yang komprehensif terkait dengan penyiapan guru IPA dan memerlukan waktu untuk perbaikan dari segi standar isi kurikulum, proses dan evaluasi.

Dalam menyusun rencana pelaksanaan pembelajaran guru bisa disebabkan sejumlah hal dianataranya kurang dipahaminya prinsip-prinsip sebagai berikut: a. Perbedaan individual peserta didik antara lain kemampuan awal, tingkat intelektual, bakat, potensi, minat, motivasi belajar, kemampuan sosial, emosi, gaya belajar, kebutuhan khusus, kecepatan belajar, latar belakang budaya, norma, nilai, dan/atau lingkungan peserta didik. $b$. Partisipasi aktif peserta didik. c. Berpusat pada peserta didik untuk mendorong semangat belajar, motivasi, minat, kreativitas, inisiatif, inspirasi, inovasi dan kemandirian. d. Pengembangan budaya membaca dan menulis yang dirancang untuk mengembangkan kegemaran membaca, pemahaman beragam bacaan, dan berekspresi dalam berbagai bentuk tulisan. Pemberian umpan balik dan tindak lanjut RPP memuat rancangan program pemberian umpan balik positif, penguatan, pengayaan, dan remedi. Penekanan pada keterkaitan dan keterpaduan antara $\mathrm{KD}$, materi pembelajaran, kegiatan pembelajaran, indicator pencapaian kompetensi, penilaian, dan sumber belajar dalam satu keutuhan pengalaman belajar. Mengakomodasi pembelajaran tematik-terpadu, keterpaduan lintas mata pelajaran, lintas aspek belajar, dan keragaman budaya. . Penerapan teknologi informasi dan komunikasi secara terintegrasi, sistematis, dan efektif sesuai dengan situasi dan kondisi.

Terkait dengan desian proses pelaksanaan harus memahami dengan bail terkait dengan ketiga ranah kompetensi tersebut memiliki lintasan perolehan (proses psikologis) yang berbeda. Sikap diperoleh melalui aktivitas "menerima, menjalankan, menghargai, menghayati, dan mengamalkan". Pengetahuan diperoleh melalui aktivitas "mengingat, memahami, menerapkan, menganalisis, mengevaluasi, mencipta". Keterampilan diperoleh melalui aktivitas "mengamati, menanya, mencoba, menalar, menyaji, dan mencipta". Karaktersitik kompetensi beserta perbedaan lintasan perolehan turut serta mempengaruhi karakteristik standar proses. Untuk memperkuat pendekatan ilmiah (scientific), tematik terpadu (tematik antar matapelajaran), dan tematik (dalam suatu mata pelajaran) perlu diterapkan pembelajaran berbasis penyingkapan/penelitian (discovery/inquiry learning). Untuk mendorong kemampuan peserta didik untuk menghasilkan karya kontekstual, baik individual maupun kelompok maka sangat disarankan menggunakan pendekatan pembelajaran yang menghasilkan karya berbasis pemecahan masalah (project based learning).

Secara umum pendekatan belajar yang dipilih berbasis pada teori tentang taksonomi tujuan pendidikan yang dalam lima dasawarsa terakhir yang secara umum sudah dikenal luas. Berdasarkan teori taksonomi tersebut, capaian pembelajaran dapat dikelompokkan dalam tiga ranah yakni: ranah kognitif, affektif dan psikomotor. Penerapan teori taksonomi dalam tujuan pendidikan di berbagai negara dilakukan secara adaptif sesuai dengan kebutuhannya masing-masing. Undang-Undang Nomor 20 Tahun 2003 tentang Sistem Pendidikan Nasional telah mengadopsi taksonomi dalam bentuk rumusan sikap, pengetahuan, dan keterampilan. Selain itu Proses pembelajaran sepenuhnya diarahkan pada pengembangan ketiga ranah tersebut secara utuh/holistik, artinya pengembangan ranah yang satu tidak bisa dipisahkan dengan ranah lainnya. Dengan demikian proses pembelajaran secara utuh melahirkan kualitas pribadi yang sikap, pengetahuan, dan keterampilan.

Pelaksanaan pembelajaran merupakan implementasi dari RPP, meliputi kegiatan pendahuluan, inti dan penutup. Dalam kegiatan pendahuluan, guru wajib: a. menyiapkan peserta didik secara psikis dan fisik untuk mengikuti proses pembelajaran; b. memberi motivasi belajar peserta didik secara kontekstual sesuai manfaat dan aplikasi materi ajar dalam kehidupan sehari-hari, dengan memberikan contoh dan perbandingan lokal, 
nasional dan internasional, serta disesuaikan dengan karakteristik dan jenjang peserta didik; c. mengajukan pertanyaan-pertanyaan yang mengaitkan pengetahuan sebelumnya dengan materi yang akan dipelajari; d. menjelaskan tujuan pembelajaran atau kompetensi dasar yang akan dicapai; dan e. menyampaikan cakupan materi dan penjelasan uraian kegiatan sesuai silabus.

Kegiatan inti menggunakan model pembelajaran, metode pembelajaran, media pembelajaran, dan sumber belajar yang disesuaikan dengan karakteristik peserta didik dan mata pelajaran. Pemilihan pendekatan tematik dan /atau tematik terpadu dan/atau saintifik dan/atau inkuiri dan penyingkapan (discovery) dan/atau pembelajaran yang menghasilkan karya berbasis pemecahan masalah (project based learning) termasuk 5E disesuaikan dengan karakteristik kompetensi dan jenjang pendidikan. Geography teachers are highly conscious of the 5E implementation (Puteh dan Nawastheen, 2013). Sesuai dengan karakteristik sikap, maka salah satu alternatif yang dipilih adalah proses afeksi mulai dari menerima, menjalankan, menghargai, menghayati, hingga mengamalkan. Seluruh aktivitas pembelajaran berorientasi pada tahapan kompetensi yang mendorong peserta didik untuk melakuan aktivitas tersebut.

Pengetahuan dimiliki melalui aktivitas mengetahui, memahami, menerapkan, menganalisis, mengevaluasi, hingga mencipta. Karakteritik aktivititas belajar dalam domain pengetahuan ini memiliki perbedaan dan kesamaan dengan aktivitas belajar dalam domain keterampilan. Untuk memperkuat pendekatan saintifik, tematik terpadu, dan tematik sangat disarankan untuk menerapkan belajar berbasis penyingkapan/penelitian (discovery/inquiry learning). Untuk mendorong peserta didik menghasilkan karya kreatif dan kontekstual, baik individual maupun kelompok, disarankan yang menghasilkan karya berbasis pemecahan masalah (project based learning).

Keterampilan diperoleh melalui kegiatan mengamati, menanya, mencoba, menalar, menyaji, dan mencipta. Seluruh isi materi (topik dan sub topik) mata pelajaran yang diturunkan dari keterampilan harus mendorong peserta didik untuk melakukan proses pengamatan hingga penciptaan. Untuk mewujudkan keterampilan tersebut perlu melakukan pembelajaran yang menerapkan modus belajar berbasis penyingkapan/penelitian (discovery/inquiry learning) dan pembelajaran yang menghasilkan karya berbasis pemecahan masalah (project based learning). Revealed significant differences in their stages of concerns regarding the $5 \mathrm{E}$ instructional model mainly in personal, management, consequence and collaboration (Puteh dan Nawastheen, 2013 ).Dalam kegiatan penutup, guru bersama peserta didik baik secara individual maupun kelompok melakukan refleksi untuk mengevaluasi: seluruh rangkaian aktivitas pembelajaran dan hasil-hasil yang diperoleh untuk selanjutnya secara bersama menemukan manfaat langsung maupun tidak langsung dari hasil pembelajaran yang telah berlangsung; memberikan umpan balik terhadap proses dan hasil pembelajaran; melakukan kegiatan tindak lanjut dalam bentuk pemberian tugas, baik tugas individual maupun kelompok; dan menginformasikan rencana kegiatan pembelajaran untuk pertemuan berikutnya.

Penilaian proses pembelajaran menggunakan pendekatan penilaian otentik (authentic assesment) yang menilai kesiapan peserta didik, proses, dan hasil belajar secara utuh. Keterpaduan penilaian ketiga komponen tersebut akan menggambarkan kapasitas, gaya, dan perolehan belajar peserta didik yang mampu menghasilkan dampak instruksional (instructional effect) pada aspek pengetahuan dan dampak pengiring (nurturant effect) pada aspek sikap. Hasil penilaian otentik digunakan guru untuk merencanakan program perbaikan (remedial) pembelajaran, pengayaan (enrichment), atau pelayanan konseling. Selain itu, hasil penilaian otentik digunakan sebagai bahan untuk memperbaiki proses pembelajaran sesuai dengan Standar Penilaian Pendidikan. Evaluasi proses pembelajaran dilakukan saat proses pembelajaran dengan menggunakan alat: lembar pengamatan, angket sebaya, rekaman, catatan anekdot, dan refleksi. Evaluasi hasil pembelajaran dilakukan saat proses pembelajaran dan di akhir satuan pelajaran dengan menggunakan metode dan alat: tes lisan/perbuatan, dan tes tulis. Hasil evaluasi akhir diperoleh dari gabungan evaluasi proses dan evaluasi hasil pembelajaran.

Penilaian hasil belajar peserta didik pada pendidikan dasar meliputi aspek: sikap; pengetahuan; dan keterampilan. Penilaian aspek sikap dilakukan melalui observasi/pengamatan dan teknik penilaian lain yang relevan, dan pelaporannya menjadi tanggungjawab wali kelas atau guru kelas; penilaian aspek pengetahuan dilakukan melalui tes 
tertulis, tes lisan, dan penugasan sesuai dengan kompetensi yang dinilai; penilaian keterampilan dilakukan melalui praktik, produk, proyek, portofolio, dan/atau teknik lain sesuai dengan kompetensi yang dinilai; Instrumen penilaian yang digunakan oleh pendidik dalam bentuk penilaian berupa tes, pengamatan, penugasan perseorangan atau kelompok, dan bentuk lain yang sesuai dengan karakteristik kompetensi dan tingkat perkembangan peserta didik.

\section{Kesimpulan}

Tingkat keterampilan guru IPA dalam mendisain perangkat pembelajaran berbasis model 5E menunjukan bahwa kemampuan masing masing sekolah relatif sama baik, Sedangkan untuk pengembangan instrumen evaluasi agak berbeda disebabkan perbedaan dalam pemahaman terkait dengan penyusunan instrumen asesmen mencakup tiga aspek pengetahuan, keterampilan dan sikap yang memenuhi standar. Selain itu sebagian besar perangkat kurang memenuhi tagihan KD khsusnya dalam penjabaran KD menjadi IPK. Model konsep pengembangan kemampuan guru IPA dalam mendisain rencana pembelajaran berbasis $5 \mathrm{E}$ yang lebih baik dan komprehensif sebaiknya diawali dari standarisasi pemahaman bapak ibu guru tersebut tentang model pembelajaran yang harus disusun secara sistematis. Selain itu, dalam workshop harus lebih fokus lagi membekali keterampilan bapak ibu guru dalam penyusunan perangkat pembelajaran yang komprehensif dan proses serta evaluasinya pada pembelajaran berbasis $5 \mathrm{E}$.

\section{Ucapan Terima Kasih}

Ucapan terima kasih disampaikan kepada Bapak Rektor Universitas Mataram atas dukungan finansial untuk pelaksanaan pengabdian kepada masyarakat dan bapak ibu guru anggota MGMP IPA Kota Mataram atas kerja sama dan partisipasi yang sangat baik dalam kegiatan pengabdian.

\section{Daftar Pustaka}

Bybee, R.W. 2014. The BSCS 5E Instructional Model: Personal Reflections and Contemporary Implications. Science. 10-13.

Bybee, R.W. et all. 2005. Doing Science: The Process of Scientific Inquiry. Center for Curriculum Development : Colorado.

Kementerian Pendidikan dan Kebudayaan. 2012. Kurikulum 2013. Jakarta; Kemendikbud

Liu, T. C. Peng, H., Wu, W. H. and Lin, M. S. 2009. The Effects of Mobile Natural-science Learning Based on the 5E Learning Cycle: A Case Study. Educational Technology \& Society, 12 (4), 344-358.

Peraturan Menteri Pendidikan Dan Kebudayaan Nomor 24 Tahun 2016 Tentang Standar Penilaian Pendidikan Dasar dan Menengah

Peraturan Menteri Pendidikan dan Kebudayaan Nomor 58 Tahun 2013 Tentang Kurikulum Sekolah Menengah Pertama/MTs

Peraturan Menteri Pendidikan Dan Kebudayaan Nomor 64 Tahun 2013 Tentang Standar Isi Pendidikan Dasar dan Menengah

Peraturan Menteri Pendidikan Dan Kebudayaan Nomor 69 Tahun 2013 Tentang Kerangka Dasar Dan Struktur Kurikulum Sekolah Menengah Atas/Madrasah Aliyah

Peraturan Menteri Pendidikan dan Kebudayaan Republik Indonesia Nomor 81a Tahun 2013 Tentang Implementasi Kurikulum

Peraturan Menteri Pendidikan dan Kebudayaan Republik Indonesia Nomor 66 Tahun 2013 Tentang Standar Penilaian Pendidikan

Peraturan Menteri Pendidikan dan Kebudayaan Republik Indonesia Nomor 65 Tahun 2013 Tentang Standar proser pendidikan Dasar dan Menengah. 
Peraturan Pemerintah Republik Indonesia Nomor 32

Tahun 2013 Tentang Perubahan Atas Peraturan Pemerintah Nomor 19 Tahun 2005

Tentang Standar Nasional Pendidikan

Puteh, S. dan Nawastheen, F. M. 2013. An Evaluation on the Implementation of $5 \mathrm{E}$ Instructional Model in Teaching Geography in Sri Lanka. Middle-East Journal of Scientific Research. 16 (5): 721-728, 2013.

Snajdr, E. 2011, Using the 5E Learning Cycle of Science Education to Teach Information Skills. .Indiana Libraries, Vol. 30, Number 2.

Tuna, A. dan Kacar, A. 2013, The Effect Of 5e Learning Cycle Model In Teaching Trigonometry On Students' Academic Achievement And The Permanence Of Their Knowledge. International Journal on New Trends in Education and Their Implications. Volume: 4 (1)

Undang-Undang Republik Indonesia Nomor 20 Tahun 2003 Tentang Sistem Pendidikan Nasional. 